\title{
Temporal Trends of Persistent Organic Pollutants in Sarasota Bay Common Bottlenose Dolphins (Tursiops truncatus)
}

\author{
John Kucklick ${ }^{1 *}$, Ashley Boggs ${ }^{1}$, Kevin Huncik', Amanda Moors', Elizabeth Davis', \\ Gina Ylitalo ${ }^{3}$, Mary McConnell ${ }^{4}$, Christina Makris ${ }^{5}$ and Randall S. Wells ${ }^{6}$
}

OPEN ACCESS

Edited by:

Juan José Alava,

University of British Columbia,

Canada

Reviewed by:

Annalisa Zaccaroni,

University of Bologna, Italy

Tanya Brown

Simon Fraser University, Canada

${ }^{*}$ Correspondence: John Kucklick john.kucklick@nist.gov

Specialty section: This article was submitted to Marine Pollution,

a section of the journal Frontiers in Marine Science

Received: 05 October 2021 Accepted: 14 January 2022

Published: 17 February 2022

Citation:

Kucklick J, Boggs A, Huncik K,

Moors A, Davis E, Ylitalo G, McConnell M, Makris $C$ and Wells RS (2022) Temporal Trends of Persistent

Organic Pollutants in Sarasota Bay Common Bottlenose Dolphins

(Tursiops truncatus).

Front. Mar. Sci. 9:763918. doi: 10.3389/fmars.2022.763918

\begin{abstract}
' Chemical Sciences Division, National Institute of Standards and Technology, Charleston, SC, United States, ${ }^{2}$ Department of Chemistry, Butler University, Indianapolis, IN, United States, ${ }^{3}$ Environmental and Fisheries Sciences Division, Northwest Fisheries Science Center, National Marine Fisheries Services, National Oceanic and Atmospheric Administration, Seattle, WA, United States, ${ }^{4}$ Department of Biology, University of Richmond, Richmond, VA, United States, ${ }^{5}$ Department of Chemistry, University of California, Santa Barbara, Santa Barbara, CA, United States, ${ }^{6}$ Mote Marine Laboratory, Chicago Zoological Society's Sarasota Dolphin Research Program, Sarasota, FL, United States
\end{abstract}

Legacy persistent organic pollutants (POPs) were measured in blubber samples collected from 196 common bottlenose dolphins (Tursiops truncatus) from 2000 to 2016 in the Sarasota Bay, Florida, ecosystem. Legacy POPs included polychlorinated biphenyl congeners ( $\Sigma$ PCB; sum of 37 congeners or congener groups), dichlorodiphenyl-trichloroethane (DDT) and transformation products ( $\Sigma D D T)$, chlordane and related compounds ( $\Sigma$ Chlor), mirex, polybrominated diphenyl ether congeners ( $\Sigma$ PBDE, sum of five congeners), dieldrin and hexachlorobenzene (HCB). All POP compounds or compound groups declined in dolphin blubber over the study period. POP classes declined at different rates within classifications (sex, adult or calf). For example, dieldrin decline in male dolphins was greatest $(-13 \%$ per year) while HCB decline was lower $(-6.3 \%$ per year). For individual POP classes, rates of decline depended on classification. For example, $\Sigma$ PCB, the POP class present at the highest concentration relative to other POPs, declined at $-8.4,-7.8$, and $-5.6 \%$ per year in adult females, adult males and calves, respectively. Overall POP declines were highest in adult males and lowest in calves. Declines in POP concentration with time based on individual dolphins resampled at different time points were consistent with declines calculated based on yearly or biennial cross-sections taken from 2000 through 2016. Overall rates of decline in Sarasota Bay bottlenose dolphins were like declines seen for Great Lakes fish and about twice the rate of decline observed in arctic temporal trend data sets. POP trends appear to have leveled off since 2009 in Sarasota Bay dolphins. For example, $\Sigma$ PCBs in calves appear to have stabilized at $21 \mathrm{mg} / \mathrm{kg}$ lipid. Recent published work on delphinids with blubber concentrations spanning those observed in the present work suggest that levels of legacy POPs currently observed in Sarasota dolphins may suppress population growth. Results from this study confirm the need for continued monitoring of POPs in the Sarasota Bay bottlenose dolphin population to see if concentrations are continuing to fall or have indeed plateaued.

Keywords: bottlenose dolphin (Tursiops truncatus), persistent organic polluntants (POPs), temporal trend, Sarasota Bay Florida, life history 


\section{INTRODUCTION}

Legacy persistent organic pollutants (POPs) are stable, bioaccumulative, and toxic chemicals that have been largely either regulated or phased out of production. These traits led to the inclusion of many legacy POPs such as polychlorinated biphenyls (PCBs), mirex and chlordane being listed in 2001 on the Stockholm Convention on Persistent Organic Pollutants, which aims to reduce global contamination by legacy POPs (UNEP, 2020). Because of high lipophilicity ( $\log \mathrm{K}_{o w}>3 \mathrm{~L} / \mathrm{kg}$ ) and resistance to metabolism, POPs accumulate and biomagnify in food webs resulting in the highest concentrations at the top of the food web in animals such as the bottlenose dolphin. Due to their potential for bioaccumulation, POP concentrations were observed in excess of $100 \mathrm{mg} / \mathrm{kg}$ lipid in delphinid blubber, such as marine mammal-eating killer whales in the Northwest Pacific Ocean, and common bottlenose dolphins living near a PCB-contaminated site near Brunswick, Georgia, United States (Krahn et al., 2009; Kucklick et al., 2011).

Accumulated legacy POPs are associated with adverse toxic effects in marine mammals. For bottlenose dolphins inhabiting the Brunswick, GA estuary, high (relative to regional dolphin populations) PCB concentrations were linked to endocrine disruption, immune, and anemia effects in dolphins. For example, total thyroxine (T4), free $\mathrm{T} 4$, total triiodothyronine (T3) and iron in the blood of dolphins significantly declined with increasing $\mathrm{PCB}$ concentrations in blubber suggesting adverse effects on growth and metabolism (Schwacke et al., 2012). Development may also be adversely affected through lactational transfer of POPs to young dolphins with highest levels transferred to the first offspring (Yordy et al., 2010c). Population effects due to maternal transfer of POPs have largely been inferred through measured effects of POPs on model organisms extrapolated through dose response relationships to marine mammals. For example, a study modeling the effects of PCBs on killer whale calf mortality and immunosuppression showed that more than $50 \%$ of global killer whale populations are at risk of collapse given current PCB blubber concentrations (Desforges et al., 2018). Populations at greatest risk of decline included transient killer whales in the Northeast Pacific Ocean feeding on marine mammals (Ross et al., 2000).

The toxic effects of legacy POPs on marine mammals and global restrictions on the manufacturing and use of legacy POPs provide motivation to monitor for declining trends especially in aquatic animals at or near the top of food webs. The most extensive effort to document temporal changes of POPs in marine mammals has largely been done in the Arctic as part of the Arctic Monitoring and Assessment Program (AMAP) which is possible because of routine sampling and analysis of marine mammal tissues by arctic countries (AMAP, 2016). Long-term (collections starting before 2000) data sets of POPs in arctic fauna and from other locations showed declines in legacy POPs (Law, 2014; Rigét et al., 2019). For example, PCB 153 declined an average of $3.8 \%$ per year, although only $38 \%$ of the 347 data sets showed a declining trend, mainly due to the lack of statistical power in the data sets. A major conclusion was that studies examining temporal changes must be mindful of the statistical power needed to define trends. Recent (since 2010) studies outside of the Arctic also confirm legacy POP are largely declining in concentration in marine mammals (Law, 2014; Lebeuf et al., 2014; Xie et al., 2021).

The objective of this study is to document the changes with time of legacy persistent organic pollutants (POPs) in the blubber of the well-studied, long-term resident population of common bottlenose dolphins (Tursiops truncatus) living in Sarasota Bay, Florida, United States. The Sarasota bottlenose dolphin population presents a unique opportunity to study the time trends of POPs in marine mammal blubber (Wells et al., 2004, 2005). Sarasota Bay bottlenose dolphins have been intensively studied since 1970 with health assessments of animals beginning in 1988 (Wells, 2020). Nearly annual health assessments provide a vital opportunity to collect high-quality data on living dolphins and, importantly for the analysis of POPs, full depth blubber samples. POP data in blubber coupled with detailed life-history information obtained through systematic monthly photo-identification surveys and health assessments provides a unique opportunity to account for known factors influencing POP blubber concentrations. This study builds on prior work on Sarasota Bay bottlenose dolphins detailing the influence of life history on contaminant profiles (Yordy et al., 2010b,c). As well, spatial comparisons of POP concentrations in bottlenose dolphins living in the Gulf of Mexico and adjacent to the US East Coast (Kucklick et al., 2011) demonstrating that POP concentrations in Sarasota Bay dolphins are near the mean of POP concentrations observed in bottlenose dolphin populations from the region suggesting that POP trends in this population may be representative of a broader geographic region. Median concentrations of total PCBs in Sarasota bottlenose dolphin males and juveniles also overlap concentrations predicted to cause population declines in killer whales (Kucklick et al., 2011). However, in the Sarasota Bay bottlenose dolphin population, cumulative first-year survival of first-born calves reported as $40 \%$ before 2000 (Wells, 2000), has seen improvement more recently, approaching $60 \%$ by 2014 (Wells, 2014) suggesting a potential decline in POP concentrations.

Legacy POPs discussed in this study include PCBs used in capacitors, chlorine production and many other applications, chlordane and related compounds, dichloro-diphenyltrichloroethane (DDT) and breakdown products, dieldrin, and mirex, mostly used as a pesticide, polybrominated diphenyl ethers (PBDEs), used as flame retardants, and the industrial chemical hexachlorobenzene. The POPs listed above were banned or phased out of production in the US. PCB formulations were banned from manufacturing in 1979 (ATSDR, 2000), chlordane's registration was canceled by the Environmental Protection Agency in 1988 (ATSDR, 2018), DDT was banned in the US in 1972, dieldrin and aldrin (aldrin converts to dieldrin in the environment) were phased out of manufacturing in 1987 (ATSDR, 2002), and the last PBDE formulation (decabromodiphenyl ether) was phased out of manufacturing in 2010 (Sutton et al., 2015). The pesticide and flame retardant, mirex, was phased out of industrial production in 1976 (ATSDR, 2019). While HCB is not manufactured, it is a biproduct of manufacturing of other chlorinated compounds and has 
not been commercially produced in the US since the late 1970s (ATSDR, 2013).

\section{MATERIALS AND METHODS}

\section{Sample Collection and Processing}

Full blubber depth wedge biopsies were collected from 196 common bottlenose dolphins during 2000-2016 as part of routine health assessments conducted by the Chicago Zoological Society's Sarasota Dolphin Research Program (SDRP) (Table 1). Samples were collected from Sarasota Bay bottlenose dolphins under a series of NOAA National Marine Fisheries Service Scientific Research permits and annual approvals by Mote Marine Laboratory's Institutional Animal Care and Use Committee. NIST has reviewed this information and has found that it is consistent with the US Government policy on animal welfare. With few exceptions, the SDRP has conducted annual capturerelease health assessments of bottlenose dolphins in the Sarasota Bay ecosystem since 1988, allowing for the collection of health data (e.g., blood chemistry, body condition, and morphometrics) and tissue samples to monitor long-term trends in population health (Wells, 2009). For this series of samples, collections were made annually from 2000 through 2016 except for 2007. Sampling occurred either in May or June; however, in 2002 and 2004 additional samples were collected in November and February, respectively. Details on blubber sampling and sample handling are given elsewhere (Yordy et al., 2010c). Animal age was determined from counting growth layer groups in teeth (Hohn et al., 1989) or in the cases of calves, knowledge of birth year from documentation during photo identification catalog (Wells et al., 2005). Subadults were divided into two categories regardless of sex; those mostly nursing (up to 4 years old) and those mostly foraging (4-10 years old). The distinction between nursing and freely foraging is based on the observation that only $16 \%$ of mothers with calves $>3$ years old are still lactating and a mean calving age for Sarasota dolphins of 10 years ( \pm 2 years) of age (Wells et al., in prep). ${ }^{1}$ On average, male and female dolphins less than this age experience similar life history traits which include nursing followed by independent foraging. Following collection, blubber samples were stored in Teflon jars at or below $-80^{\circ} \mathrm{C}$ until analysis as detailed elsewhere (Yordy et al., 2010c).

Blubber samples were analyzed for PCB congeners or congener groups $(18,28+31,52,49,44,74,95,66,101$, $99,87,110,151,149,118,153+132,105,138+163,158$, $187,183,128,177,202,156,201,180+193,200,170,199$, $203+196,208,195,207,194,206$, and 209), DDT $\left(2,4^{\prime}-\right.$ and $4,4^{\prime}$-DDT, DDE and DDD) and metabolites, chlordane and metabolites (cis- and trans-nonachlor, cis- and trans-chlordane), hexachlorobenzene, mirex, dieldrin and PBDE congeners $(47,99$, 100, 153, and 154) (Supplementary Table 1). Details regarding sample preparation are provided elsewhere (Litz et al., 2007)

${ }^{1}$ Wells, R. S., Scott, M. D., Hohn, A. A., Sweeney, J. C., Townsend, F. I., Allen, J. B., et al. (in preparation). Life history, reproductive biology and demographic parameters for common bottlenose dolphins (Tursiops truncatus) in Sarasota Bay, FL. Front. Mar. Sci.
TABLE 1 | Number of common bottlenose dolphin samples collected per year by sex and age class.

\begin{tabular}{|c|c|c|c|c|c|c|}
\hline Year & Male & Female & Adult male & $\begin{array}{c}\text { Adult } \\
\text { female }\end{array}$ & $\begin{array}{c}\text { Mostly } \\
\text { nursing } \\
\text { calves }\end{array}$ & $\begin{array}{c}\text { Mostly } \\
\text { foraging } \\
\text { calves }\end{array}$ \\
\hline 2000 & 12 & 14 & 7 & 9 & 6 & 4 \\
\hline 2001 & 4 & 7 & 0 & 5 & 4 & 2 \\
\hline 2002 & 5 & 10 & 1 & 5 & 7 & 2 \\
\hline 2003 & 4 & 5 & 1 & 2 & 2 & 4 \\
\hline 2004 & 14 & 14 & 6 & 9 & 7 & 6 \\
\hline 2005 & 8 & 9 & 2 & 5 & 5 & 5 \\
\hline 2006 & 8 & 0 & 5 & 0 & 2 & 1 \\
\hline 2007 & 0 & 0 & 0 & 0 & 0 & 0 \\
\hline 2008 & 0 & 4 & 0 & 2 & 2 & 0 \\
\hline 2009 & 3 & 3 & 1 & 1 & 4 & 0 \\
\hline 2010 & 3 & 1 & 2 & 1 & 1 & 0 \\
\hline 2011 & 10 & 1 & 3 & 1 & 4 & 3 \\
\hline 2012 & 11 & 5 & 8 & 3 & 4 & 1 \\
\hline 2013 & 7 & 6 & 2 & 2 & 4 & 5 \\
\hline 2014 & 0 & 9 & 0 & 4 & 4 & 1 \\
\hline 2015 & 4 & 6 & 1 & 4 & 4 & 1 \\
\hline 2016 & 4 & 5 & 2 & 3 & 4 & 0 \\
\hline Total & 97 & 99 & 41 & 56 & 64 & 35 \\
\hline
\end{tabular}

and summarized here. For samples analyzed by NIST, 0.5$1.0 \mathrm{~g}$ full blubber depth samples were macerated while frozen and then mixed with approximately $30 \mathrm{~g}$ of granular sodium sulfate, transferred to pressurized fluid extraction cells and then extracted with dichloromethane by pressurized fluid extraction (Thermo/Dionex ASE 200). Prior to extraction, a suite of carbon13 labeled internal standards were added to samples. Calibrants were also prepared using NIST Standard Reference Material (SRM) Solutions that covered the range of analytes reported. Blanks and SRM 1945 Organics in Whale Blubber were analyzed with each batch of 30 samples. Sample and calibrant extracts were cleaned up by size exclusion chromatography followed by alumina solid phase extraction prior to analysis by gas chromatography mass spectrometry (GC-MS). Percent lipid in blubber was determined gravimetrically through subsamples of the dichloromethane extract prior to cleanup.

Samples collected in 2010 and 2011 were analyzed by the National Oceanic and Atmospheric Administration's Northwest Fisheries Science Center (NOAA/NWFSC) (Sloan et al., 2004; Schwacke et al., 2014). Both NIST and the NOAA/NWFSC have collaborated extensively on POP analysis through interlaboratory comparisons using marine mammal tissues and jointly include the analysis of SRM 1945 Organics in Whale Blubber as a control during analysis (Kucklick et al., 2008, 2010). Blubber samples were analyzed as detailed elsewhere (Sloan et al., 2004). Briefly, samples were homogenized in their original container and then mixed with both sodium sulfate and magnesium sulfate to remove water. Samples were then transferred to pressurized fluid extraction cells and extracted with dichloromethane. Lipid mass fraction was determined through subsampling of the dichloromethane extract. Sample extracts were cleaned up 
using a combination of size exclusion chromatography and silica/alumina column chromatography. Compounds of interest were quantified using a combination of an external calibration curve, internal standards added to the samples prior to extraction and internal standards added prior to injection of samples on the GC-MS. Compounds were separated using a $60 \mathrm{~m} \times 0.25 \mathrm{~mm} \times$ $0.25 \mathrm{~mm}$ methylpolysiloxane column (5\% phenyl).

Data from the two laboratories were combined omitting compounds not in common. The sum of PCB congeners ( $\Sigma$ PCB) represented the sum of 37 congeners (IUPAC designation): 18, $28+31,52,49,44,74,95,66,101,99,87,110,151,149,118$, $153+132,105,138+163,158,187,183,128,177,202,156$, $201,180+193,200,170,199,203+196,208,195,207,194,206$, and 209. The sum of polybrominated diphenyl ethers is the sum of congeners ( $\Sigma$ PBDE): 47, 99, 100, 153, and 154. The sum of chlordane ( $\Sigma$ Chlor) is the sum of cis- and trans-chlordane and non-achlor. The sum of DDTs ( $\Sigma D D T$ ) is the sum of 2,4'- and 4,4 '-DDD, DDE and DDT. Also quantified in common between the two laboratories were mirex, hexachlorobenze (HCB), and dieldrin. Data for samples from 2000 through 2005 were analyzed by NIST and published elsewhere (Yordy et al., 2010c); data from 2010 and 2011 were produced by NWFSC (Schwacke et al., 2014); all other data used for this work were generated by NIST for this study and are unpublished.

\section{Statistical Analysis}

Data were first examined in JMP 11 (SAS, Institute, Cary, North Carolina, United States) using backward stepwise regression with $\Sigma$ PCB, $\Sigma$ PBDE, $\Sigma$ Chlor, $\Sigma$ DDT, mirex, HCB or dieldrin as the dependent variable and year, percent lipid, sex and age as independent variables and the interaction between age and sex. Variables were included in the model if significant at $p<0.05$. Time trends were assessed using PIA (Plot and Image Analysis) software developed for the Artic Monitoring and Assessment Program (AMAP, 2016) to detect temporal trends in the arctic environment (Bignert, 2013). The program uses the geometric mean annual values to reduce the impact of outliers as well as a three-point smoother across years testing the null hypothesis that there is no log-linear trend in concentration with time. If the null hypothesis is rejected, the program gives output of the magnitude and direction (increasing or decreasing) of the temporal trend as well as the statistical power needed to determine the trend. Further details on the PIA program are given elsewhere (Bignert, 2013; Rigét et al., 2019). Samples in this study were lipid-normalized as this parameter was significant in the stepwise regression and most published studies on POPs in marine mammals present lipid normalized data. Age was included as a covariate in the PIA program for males, adult males, and calves and adult males combined as this variable was kept in the stepwise regression mode.

\section{Change in Concentration Calculated Based on Recapture-Release}

Given that the population of dolphins studied was resampled repeatedly, there were many dolphins that were captured and released multiple times. This provided an opportunity to calculate the change in concentration. The change (\%) in POP concentration per year in pairs was calculated as follows:

$$
\begin{aligned}
& ((\text { earlier date }[\mathrm{POP}]-\text { later date }[\mathrm{POP}]) / \text { earlier data }[\mathrm{POP}]) / \\
& \text { interval }(\text { year }) \times 100
\end{aligned}
$$

where $[\mathrm{POP}]$ is the POP concentration (ng/g lipid). If a dolphin was sampled more than twice, the change was calculated sequentially based on the previous capture-release. For example, if a dolphin was sampled on three different dates, there would be two values for $\%$ change/year.

\section{RESULTS AND DISCUSSION}

POP data were analyzed for 196 bottlenose dolphins that were sampled during 2000 through 2016, with samples collected yearly except for 2007 (Table 1). All age classes were sampled most years except for 2006, 2008, 2011, and 2014. Males were targeted for health assessment in 2010 and 2011 as the Sarasota Bay dolphin population was used as a reference population for comparative work done in Barataria Bay, Louisiana as part of the Deepwater Horizon oil spill damage assessment (Schwacke et al., 2014). $\Sigma$ PCB were present in the highest concentration regardless of age class, followed by $\Sigma$ DDT, $\Sigma$ Chlor, mirex, $\Sigma$ PBDE, dieldrin and HCB (Figures 1-4 and Supplementary Figures 1, 2). Five PCB congeners, 99, 153, $138+163,187$, and $180+193$ accounted for $67 \%$ of $\Sigma$ PCB in males and $63 \%$ in females. The major individual compounds in each POP classes (percent of summed class in males and females, respectively) were 4,4'-DDE (95 and 91\%) trans-non-achlor (85 and 77\%), and PBDE 47 (67 and $62 \%)$. POP concentrations were overall highest in adult males and lowest in adult females with the relative proportions of POPs roughly the same regardless of age or sex. For example, median $\Sigma$ PCB concentrations in adult male bottlenose dolphins were $44.9 \mathrm{mg} / \mathrm{kg}$ lipid (range $17.6 \mathrm{mg} / \mathrm{kg}$ to $687.5 \mathrm{mg} / \mathrm{kg}$ ) vs. $2.63 \mathrm{mg} / \mathrm{kg}$ (range $0.56 \mathrm{mg} / \mathrm{kg}-22.5 \mathrm{mg} / \mathrm{kg}$ ) in adult females. Concentrations of POPs in adult females are known to be substantially reduced primarily through nursing (Wells et al., 2005; Yordy et al., 2010c). Median POP concentrations in adult male dolphins were influenced by very high concentrations observed in two male dolphins with low lipid content relative to the average lipid content in adult male dolphin blubber (38.9\% $\pm 14.7 \%$ mass fraction). Specifically, outlier examples include a 43-year-old male dolphin sampled in 2000 (3.4\% mass fraction lipid) and a 34-year-old male dolphin sampled in 2006 (3.5\% lipid mass fraction) with $\Sigma$ PCB $645 \mathrm{mg} / \mathrm{kg}$ lipid and $688 \mathrm{mg} / \mathrm{kg}$ lipid, respectively. An additional animal sampled in 2006, a 17-year-old male, also had lipid content of $8.8 \%$ mass fraction yielding a $\Sigma$ PCB concentration of $204 \mathrm{mg} / \mathrm{g}$ lipid. These animals were not removed from the data set for time trend analysis as the method utilizes geometric mean concentrations thus limiting the influence of outliers. Median concentrations of $\Sigma$ PCBs (as an example), in nursing calves $(24.2 \mathrm{mg} / \mathrm{kg}$; range $7.4 \mathrm{mg} / \mathrm{kg}$ lipid to $255 \mathrm{mg} / \mathrm{kg}$ lipid) were between adult males and females. 

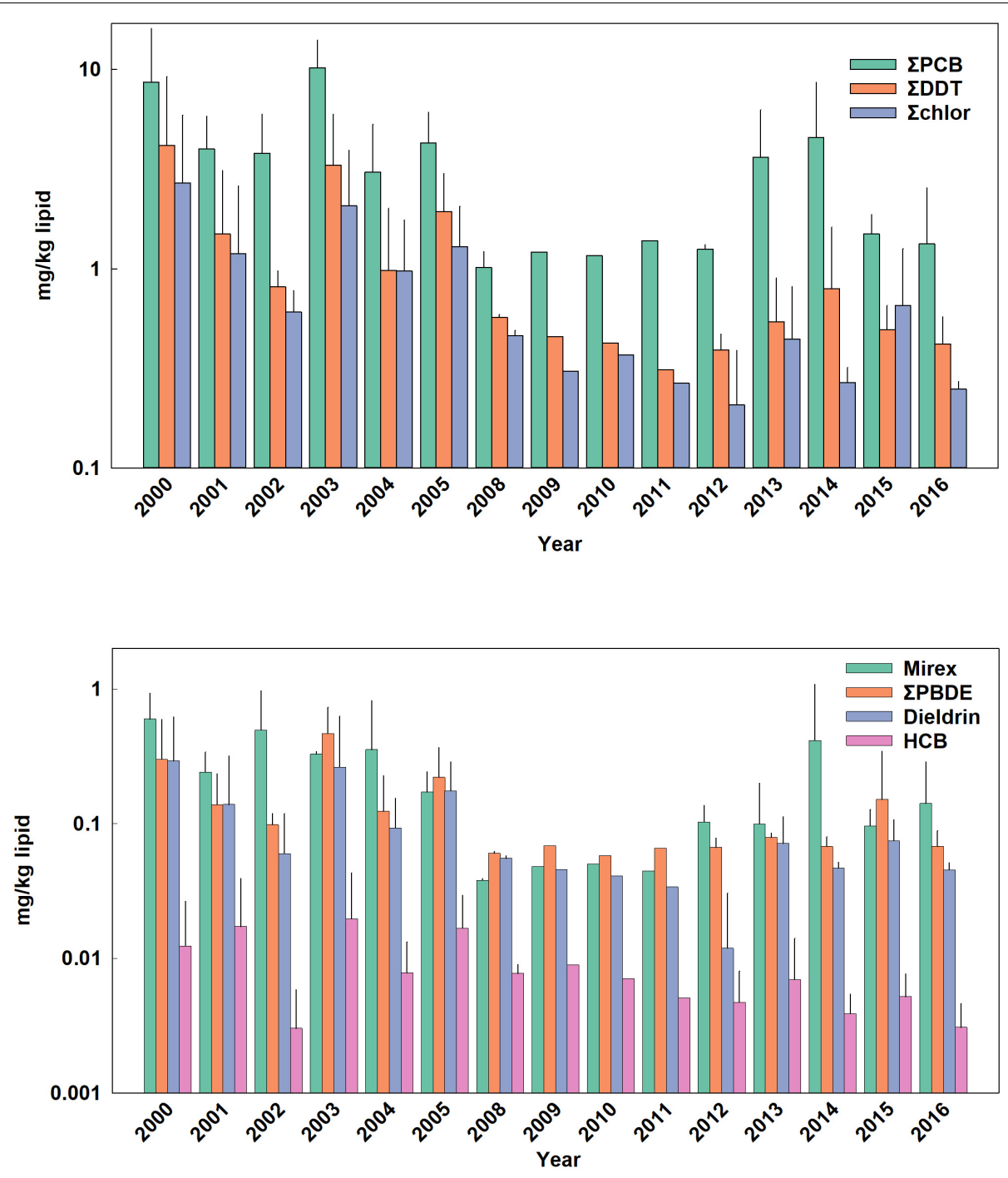

FIGURE 1 | Temporal trends of POPs in adult female bottlenose dolphins. Bars are mean \pm standard deviation. Values in parentheses are for error bars that are off scale.

\section{Time Trends of Individual Persistent Organic Pollutants or Persistent Organic Pollutant Classes}

Time trends were determined for lipid-normalized POPs in males and females in the following categories: males, females, adult males, adult females, mostly nursing dolphins and foraging calves. Animal age was included as a covariate in males, adult males, and males and calves as this factor was found to be a significant contributor to POP concentrations. Males and calves were combined as a subgroup based on prior contaminant work on delphinids (Tuerk et al., 2005a,b).

\section{Polychlorinated Biphenyls}

Polychlorinated biphenyls were used extensively in North America in a variety of applications including dielectric fluids, paints, and the chlorine production industry (Diamond et al.,
2010). PCBs were phased out starting in 1974 with uses limited to those in closed systems such as transformers; however by this time they had contaminated the global environment (ATSDR, 2000). Like other POPs discussed in this work, PCBs originate from a variety of local and distant sources; no major point sources of PCBs in the Sarasota Bay area have been identified. POPs are transported from source to receptor locations through atmospheric deposition as PCBs are semivolatile and stable in the atmosphere and readily partition into water through atmospheric deposition and gas exchange (Bidleman and McConnell, 1995). PCBs and other POPs are also present in sediment reservoirs where they can lead to food web accumulation especially adjacent to locations with known use (Maruya and Lee, 1998; Litz et al., 2007; Wirth et al., 2014).

Temporal trends of $\Sigma$ PCBs in the Sarasota Bay bottlenose dolphin population are shown in Table 2. $\Sigma$ PCBs significantly declined in all bottlenose dolphin classifications except bottlenose 

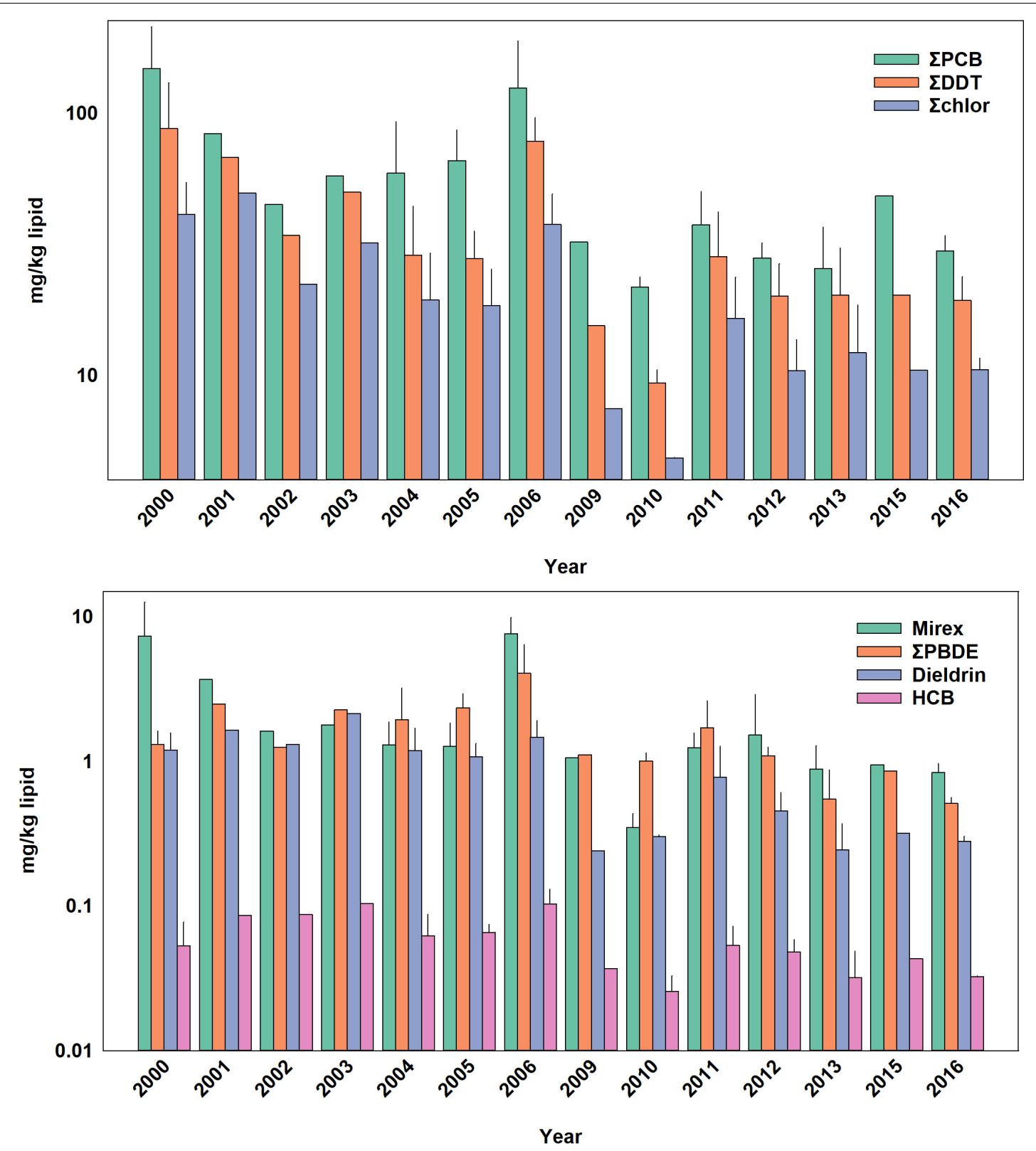

FIGURE 2 | Temporal trends of POPs in adult male bottlenose dolphins. Bars are mean \pm standard deviation. Values in parentheses are for error bars that are off scale.

dolphin females. Rates of decline were highest for adult females $(-8.4 \%$ per year) and lowest for nursing calves $(-4.5 \%$ per year). Except for calves, PCB rates of decline are in the range of those generally observed in Great Lakes fish (Table 3). There are more temporal trend data available for artic food webs. PCB declines in the Arctic are dependent on location with the highest rates (up to $-5 \%$ per year) observed in seals for more eastern than western locations (Rigét et al., 2019). PCB levels also decreased with time in blubber of bowhead whales (Balaena mysticetus) harvested near the North Slope, Alaska from 2006 to 2015, though the decline was not significant (Bolton et al., 2020).

\section{Dichloro-Diphenyl-Trichloroethane and Transformation Products}

DDT has a different use history than PCBs as it was exclusively used as a pesticide largely to control for disease-carrying mosquitos and agricultural pests. DDT was banned in the US in 1973 with most other global uses of DDT phased out by 2010 (ATSDR, 2009). However, DDT is still used in India and Africa for vector control (van den Berg et al., 2012). In most biota, DDT is transformed to DDE and in sediments DDT is transformed to DDD. DDT in marine mammals is almost exclusively present as the metabolite, 4,4'-DDE. 

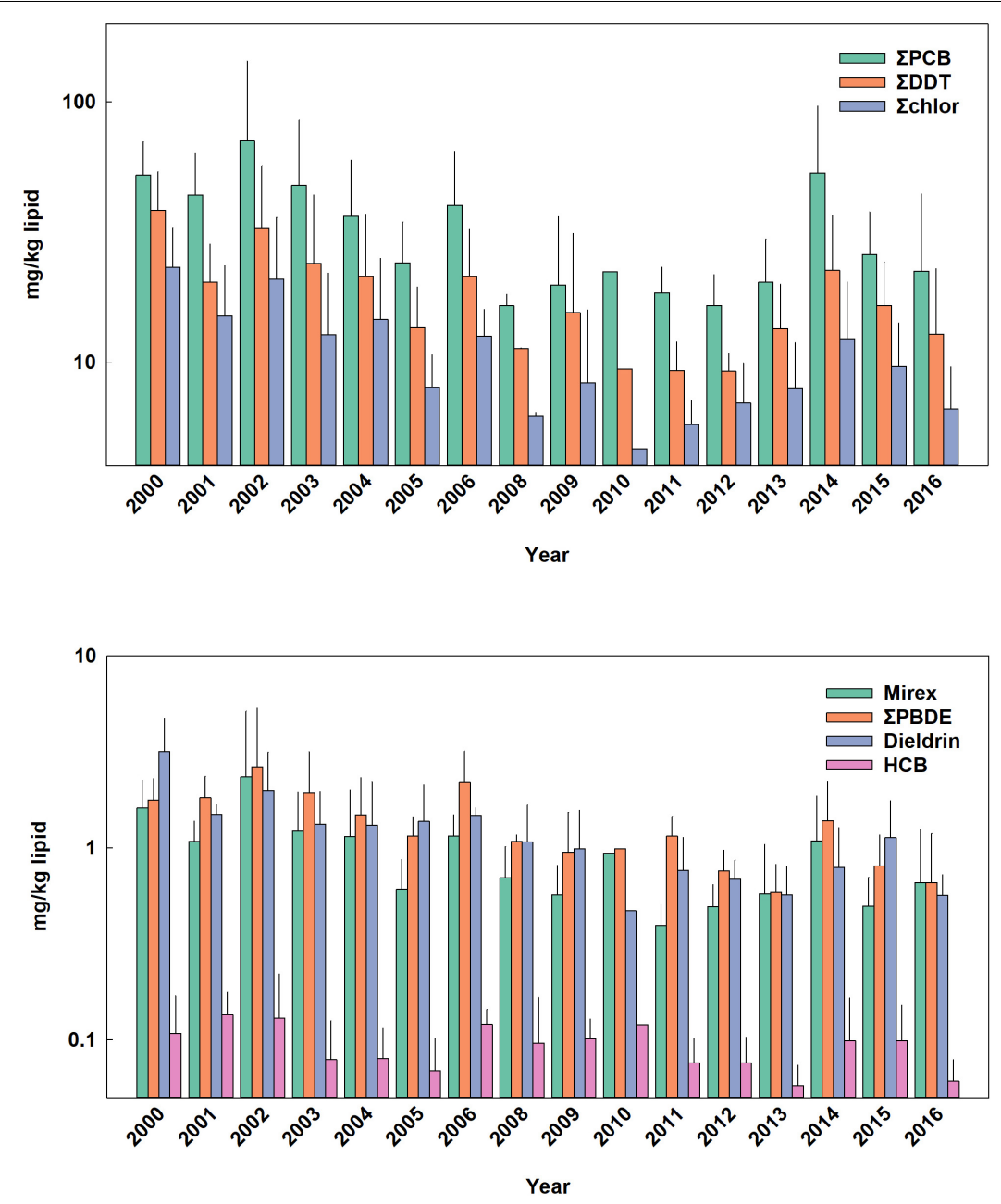

FIGURE 3 | Temporal trends of POPs in calf (combination of nursing and foraging) bottlenose dolphins. Bars are mean \pm standard deviation. Values in parentheses are for error bars that are off scale.

$\Sigma$ DDT in Sarasota Bay bottlenose dolphins, like $\Sigma$ PCBs, showed significant declines except for the female category. The largest decline was observed for adult females $(-9.2 \%$ per year) and the smallest decline was for nursing calves $(-4.0 \%$ per year). Overall, rates of decline of $\Sigma$ DDTs in Sarasota bottlenose dolphins were less than those observed in Great Lakes fish, although rates of decline in fish species were somewhat variable while rates of decline in arctic fauna averaged -4.2 to $-6.0 \%$ per year (Table 3; Rigét et al., 2019; Bolton et al., 2020). $\mathrm{DDDT}$ in adult females and males, while differing markedly in lipid-based concentrations, declined at similar rates likely reflecting declining rates in forage (Table 3 ).

\section{Chlordanes}

Chlordane, like DDT, is an insecticide and a technical mixture, although chlordane had more various uses including on house foundations for termite control, agriculture and on turfgrass (Dearth and Hites, 1991). Because chlordane registration was canceled in 1988, most chlordane used in South Florida was probably for termite prevention in homes built before 1988
(ATSDR, 2018). $\Sigma$ Chlor as a proportion of total POPs, is generally higher in the Sarasota bottlenose dolphin population relative to other bottlenose dolphin populations likely due to local use for termite control (Kucklick et al., 2011). $\Sigma$ Chlor showed the steepest declines (Table 2) in adult females and males $(-10 \%$ per year and $-9.8 \%$ per year) with nursing calves again showing a slower rate $(-4.4 \%$ per year). By comparison, cis-nonachlor significantly declined in lake trout at an average of $-10 \% \pm 4.3 \%$ per year in three of five lakes (Huron, Ontario, and Michigan) during 1999 through 2009 (Chang et al., 2012). Likewise, transnonachlor declined at $-4.6 \%$ per year in 15 biotic sample time series from the Arctic (Rigét et al., 2019).

\section{Polybrominated Diphenyl Ethers}

Polybrominated diphenyl ether mixtures were used extensively since the 1970 s as a flame retardant in furniture, wiring insulation, plastics and construction materials (de Wit et al., 2010). The penta-mixture of PBDEs was phased out of production in the early 2000s followed by decabromo diphenyl ether in 2014 (UNEP, 2020). In marine mammals PBDE-47 

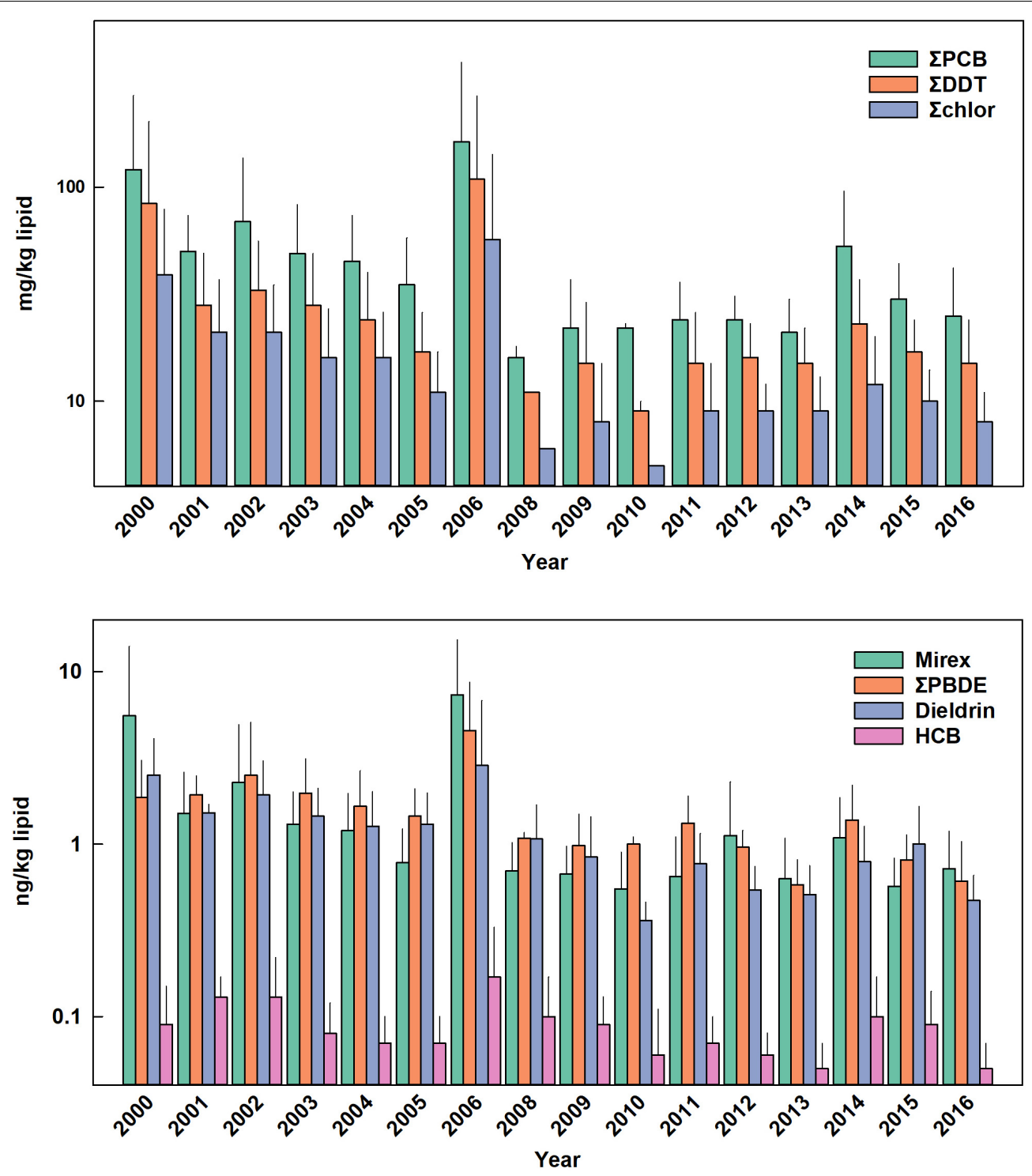

FIGURE 4 | Temporal trends of POPs in adult male and calf bottlenose dolphins. Bars are mean \pm standard deviation. Values in parentheses are for error bars that are off scale.

$\left(2,2^{\prime}, 4,4^{\prime}\right.$-tetrabromodiphenyl ether) usually dominates the PBDE profile as it is the main congener in the penta-PBDE mixture, is a decomposition product of higher brominated PBDEs, and has a greater biomagnification potential than other PBDEs (Kelly et al., 2008).

$\Sigma$ PBDEs concentrations significantly declined in all bottlenose dolphin classes shown in Table 2 with numerically higher declines in males and adult males $(-7.7$ and $-7.8 \%$ per year) although rates of decline in the other classifications were similar. Many temporal trend studies of aquatic biota capture the use restrictions of PBDEs often showing increasing trends up to the early 2000s followed by declines (Braune et al., 2015). Long-term ( $>10$ year) data sets spanning this period often do not show significant temporal trends as biotic concentrations rise and then fall during the time series (Rigét et al., 2019; Bolton et al., 2020). Such a pattern was not apparent in the current data set with concentrations steadily declining across the time frame of when PBDEs were phased out of production in the early 2000s (Figures 1-4).

\section{Hexachlorobenzene}

Hexachlorobenzene is a compound with few intentional uses and appears to originate as an unintended byproduct released during the manufacture of other chlorinated compounds such as chlorinated solvents and pesticides (ATSDR, 2013). Consequently, one would expect that with the overall decline in organochlorine manufacturing, $\mathrm{HCB}$ concentrations in the environment would follow suit. However, $\mathrm{HCB}$ is one of the most volatile of the compounds in this study and is readily distributed globally through the atmosphere. Concentrations 
TABLE 2 | Temporal trend statistics for POP classes determined using the PIA software.

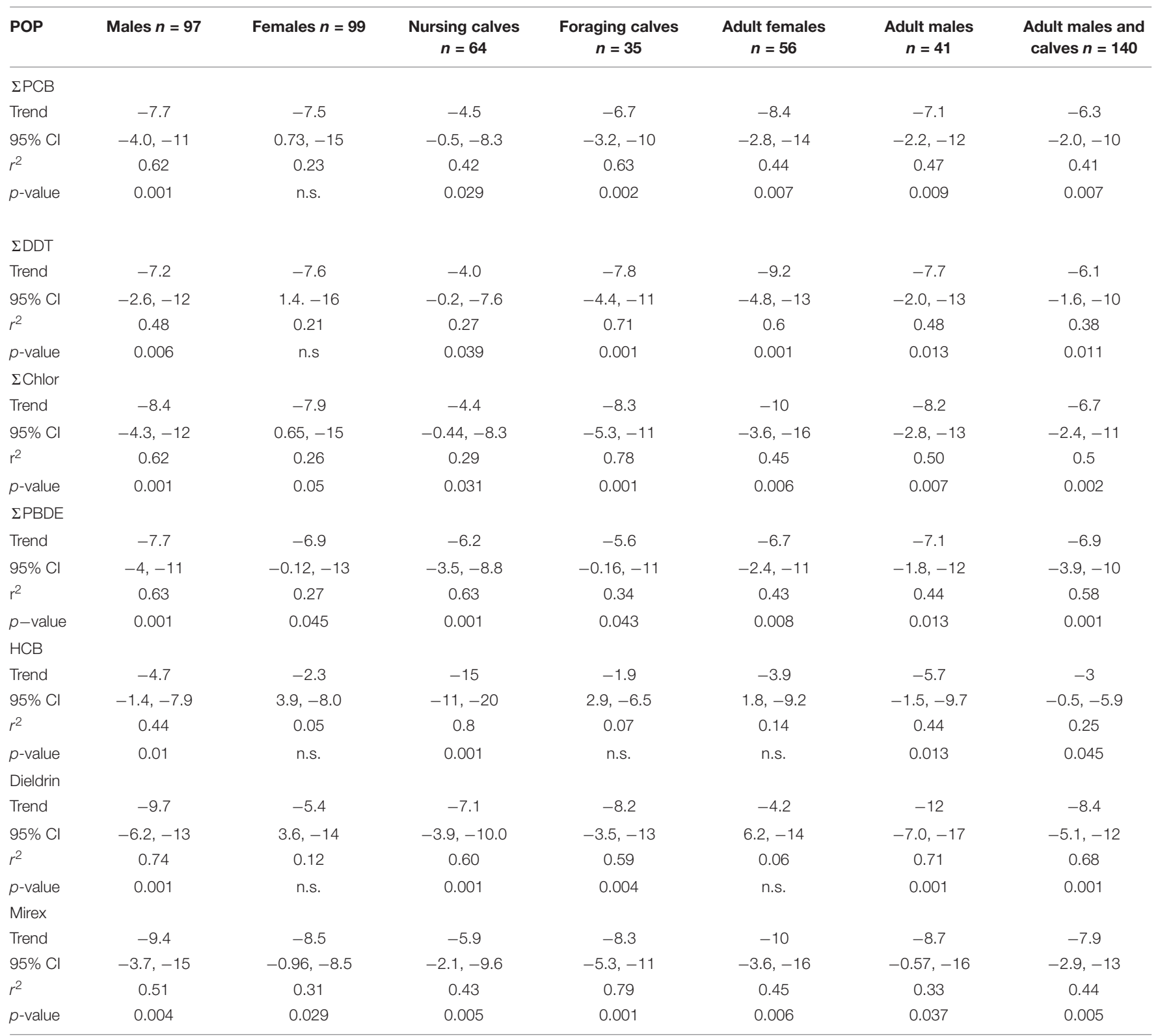

Trend is percent change per year.

may be controlled by distant global sources where chlorinated chemicals are still being manufactured (Becker et al., 2012; Pozo et al., 2017).

$\mathrm{HCB}$ was the compound in the lowest concentration in Sarasota bottlenose dolphins (Supplementary Table 1 and Figures 1-4) and concentration declines for HCB were the lowest of the POPs included in the study (Table 2). Concentration declines were significant for males, adult males, and combined males and calves, and nursing calves and were -4.7, -6.3, -3 , and $-15 \%$ per year, respectively (Table 2 ). The reason for relatively high rate of decline in nursing dolphins is not clear. Decline for the three significantly decreasing groups were slightly faster than those seen in arctic biotic time trend data sets (ranging from -2.0 to $-2.6 \%$ ) (Rigét et al., 2019; Bolton et al., 2020), however only $36 \%$ of data sets showed significant declines and two data sets showed significant increases in HCB with time. Similarly, temporal trends of $\mathrm{HCB}$ in air at different arctic monitoring stations showed both increasing and declining HCB trends depending on location again suggesting environmental concentrations are likely supported by ongoing HCB emissions (Hung et al., 2016).

\section{Dieldrin}

Like chlordane, dieldrin was used as an insecticide and found wide use as a termiticide in home foundations. The last two applications of dieldrin (root treatment and termiticide) 
TABLE 3 | Example temporal changes in species from other locations.

\begin{tabular}{|c|c|c|c|c|c|c|c|}
\hline Location & Species & PCBs & DDTs & Dieldrin & Mirex & Years & References \\
\hline Lake Ontario & Eel & $-10 \%$ & $-8 \%$ & & $-9 \%$ & 1976-2006 & Byer et al., 2015 \\
\hline Lake Ontario & Lake Trout & $-3.5 \%$ & $-11 \%$ & $-11 \%$ & -9.1 & 1999-2009 & Chang et al., 2012 \\
\hline Lake Ontario & Eel & $-10 \%$ & $-10 \%$ & & $-5 \%$ & 1976-2006 & Byer et al., 2015 \\
\hline Lake Ontario & Lake Trout & - to $-0 \%$ & $-11 \%$ & & $-3 \%$ & 1976-2006 & Byer et al., 2015 \\
\hline Lake Ontario & Lake Trout & -7 to $-10 \%$ & $-9 \%$ & & $-7 \%$ & 1976-2006 & Byer et al., 2015 \\
\hline Lake Erie & Lake Trout & $n . s^{*}$ & n.s & n.s & n.s. & 1999-2009 & Chang et al., 2012 \\
\hline Lake Superior & Lake Trout & n.s & n.s. to $-11 \%$ & n.s. & - & 1999-2009 & Chang et al., 2012 \\
\hline Lake Michigan & Lake Trout & $-8.1 \%$ & $-16 \%$ & $-15 \%$ & - & 1999-2009 & Chang et al., 2012 \\
\hline Lake Huron & Lake Trout & $-3.5 \%$ & $-11 \%$ & $-16 \%$ & $-6.6 \%$ & 199-2009 & Chang et al., 2012 \\
\hline Greenland & Polar Bear (male) & $-2 \%$ & $-3 \%$ & & - & 1989-2010 & Dietz et al., 2013 \\
\hline Sea of Japan & Finless Porpoise & n.s. & - & & - & 2000-2007 & Lam et al., 2009 \\
\hline $\begin{array}{l}\text { St. Lawrence } \\
\text { Estuary }\end{array}$ & Beluga whales (Males) & n.s. & $-4.5 \%$ & & $-4 \%$ & 1987-2004 & Lebeuf et al., 2014 \\
\hline Greenland & Ringed Seals & $-6 \%$ & $-8 \%$ & & - & 1994-2006 & Vorkamp et al., 2008 \\
\hline Alaska & Fur Seals (male) & n.s. & n.s. & & - & 1989-2007 & Reiner et al., 2016 \\
\hline Alaska & Beluga whales & n.s. & n.s. & & n.s. & 1989-2006 & Hoguet et al., 2013 \\
\hline Alaska & Bowhead whale & n.s. & $-6.1 \%$ & $-3.0 \%$ & - & $1997-2015$ & Bolton et al., 2020 \\
\hline
\end{tabular}

*n.s. denotes no statistically significant trend.

were voluntarily withdrawn by the manufacturer in 1974 (ATSDR, 2002). While temporal trends were negative for all bottlenose dolphin classes in Table 2, declines were non-significant in females and adult females. Dieldrin declines were most rapid in adult males $(-9.7 \%$ year $)$ and slower in nursing calves $(-5.4 \%$ per year). Relatively large declines in dieldrin were observed in the Great Lakes with the largest observed in Lake Huron lake trout $(-16 \%$ per year; Table 3$)$. Declines in arctic fauna were reported to be $-3 \%$ per year on average in the 10 data sets showing significant temporal changes (Rigét et al., 2019; Bolton et al., 2020).

\section{Mirex}

Mirex is a highly chlorinated compound with a number of uses including as a fire retardant and a pesticide primarily used on invasive fire ants (Kaiser, 1978). Mirex was commercially introduced to the US market in 1959 and largely manufactured by the Hooker Chemical Company in Niagara Falls, New York. Manufacturing of mirex largely ceased in the mid-1970s but not before mirex was used extensively throughout the Southeast US to control fire ants (Kaiser, 1978; ATSDR, 2019). Mirex is also a global contaminant being found, for instance, in the blood of giant petrel seabirds inhabiting the Southern Ocean (Colabuono et al., 2016).

Mirex concentrations were significantly declining (Table 2) in all dolphin classifications with the largest declines observed for adult female and male dolphins $(-9.4$ and $-8.5 \%$ per year). Again, nursing calves showed the lowest decline $(-5.9 \%$ per year). By comparison, fish from Lake Ontario, which was heavily contaminated with mirex from the Hooker Chemical Company, also show significant declines, yet not as great as declines observed in Sarasota bottlenose dolphins (Tables 3, 4).

\section{Persistent Organic Pollutant Declines Based on Repeated Sampling Over Time}

A unique attribute of this data set is that POP values are available for animals captured and released several times during over the period of the study. Unlike the cross-sectional data used to derive most temporal trend statistics (Rigét et al., 2019), the data in the current study provides an opportunity to examine POP changes longitudinally. There were 39 recapture pairs (a capture-release followed by another capture-release later) represented in the data, with 18 and 21 pairs for females and males recaptured, respectively. Most individuals were recaptured once $(n=13$ and $n=15$ for females and males, respectively), however some were recaptured twice ( $n=4$ and $n=5)$ or three times $(n=1)$ for both females and males, respectively.

Median percent changes in POP concentration per year based on recapture are presented in Table 4 . The values do not include whether the dolphin was a calf or an adult (as defined here) as some recapture intervals spanned life history classes. Overall, the median\%POP change per year was negative for both male and female dolphins indicating overall declining concentrations with year in individuals. Median per year changes in males ranged from -3.4 for $\Sigma$ Chlor to $-10.5 \%$ for dieldrin and $-8.1 \%$ for $\Sigma$ Chlor to $-9.4 \%$ for dieldrin in females. Declines across POP class or compound were more variable in males relative to the PIA results, while female rates were more consistent for reasons that are not clear. While rates of change were consistently negative, they were variable in an individual dolphin as shown by the range of concentration change between captures (Table 4). Variability was not unexpected given the large influence of life history and other factors on POP concentrations. Factors affecting POP blubber concentrations at any given time include whether an animal is nursing or independently foraging, birth order, health 
TABLE 4 | Percent declines per year in POPs based on recapture.

\begin{tabular}{|c|c|c|c|c|c|c|c|c|}
\hline Sex & & $\Sigma$ PCB & $\Sigma$ PBDE & 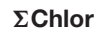 & $\Sigma D D T$ & НСB & Dieldrin & Mirex \\
\hline Males & Median & -3.7 & -7.4 & -3.4 & -3.2 & -6.4 & -10.5 & -3.7 \\
\hline \multirow[t]{3}{*}{$n=21$} & Stdev & 13 & 15 & 21 & 15 & 15 & 13 & 16 \\
\hline & Min & -30 & -43 & -29 & -29 & -30 & -33 & -31 \\
\hline & Max & 27 & 25 & 65 & 35 & 31 & 22 & 41 \\
\hline Females & Median & -8.6 & -9.0 & -8.1 & -8.7 & -8.6 & -9.4 & -8.2 \\
\hline \multirow[t]{3}{*}{$n=18$} & Stdev & 34 & 23 & 13 & 11 & 22 & 72 & 12 \\
\hline & Min & -27 & -29 & -18 & -26 & -32 & -23 & -28 \\
\hline & Max & 148 & 89 & 32 & 18 & 71 & 247 & 32 \\
\hline
\end{tabular}

status, body condition, growth rate, POP concentrations in prey, foraging area, POP metabolism, and if a female, if the animal has had a calf (Yordy et al., 2010c; Cadieux et al., 2016). Given that all samples analyzed were from full blubber depth samples, stratification of POPs in blubber, which has been observed in other work, was not a factor in the current data set (Ellisor et al., 2013). Declining concentrations of POPs in individual dolphins based on recapture (longitudinal) confirms results calculated using cross-sectional data (see section "Time Trends of Individual Persistent Organic Pollutants or Persistent Organic Pollutant Classes").

\section{Implications for the Sarasota Bay Bottlenose Dolphin Population}

Levels of POPs are declining across all contaminant groups in the Sarasota Bay bottlenose dolphin population regardless of age or sex. Overall rates are faster than observed in arctic time trend data sets and are more comparable to declines observed in Great Lakes fish, which is a location with several long-term data sets. Clearly, restrictions and voluntary phasing out of POPs have had a positive impact on trends in the Sarasota Bay environment as reflected in bottlenose dolphins. Conversely, POP declines observed over 16 years in this data set suggest that POP concentrations were much higher in bottlenose dolphin blubber in years prior to the beginning of our study in 2000. This is especially for PCBs and DDT that were banned 25 years prior to 2000 yet persist in the environment. For example, conservatively assuming $\Sigma$ PCBs are declining linearly (as opposed to exponentially) with time in bottlenose dolphins, using median $\Sigma$ PCB levels in 2000 and extrapolating back to 1990, suggests that concentrations in adult male bottlenose dolphins could have exceeded $370 \mathrm{mg} / \mathrm{kg}$ lipid while calves (nursing and foraging) had a concentration of $110 \mathrm{mg} / \mathrm{kg}$ lipid. Encouragingly, the dolphin population increased from approximately 100 individuals since 1976 and 1983 to 158 individuals in 2015 suggesting that POP declines result in growth of the larger Sarasota Bay dolphin population (Irvine et al., 1981; Wells and Scott, 1990; Tyson and Wells, 2016).

While overall POPs concentrations are declining, shorter term (1-2 year) rise in blubber concentration may occur. Sarasota Bay experiences regular toxic algae blooms of the red tide organism Karenia brevis resulting in extensive fish kills causing decreasing dolphin prey availability (Van Dolah, 2000; Gannon et al., 2009). A particularly large red tide bloom occurred in Sarasota By in 2005 and 2006 causing a nearly 50\% decline in the Sarasota Bay fish population (Gannon et al., 2009). When dolphins are nutritionally stressed, blubber lipid is mobilized to in order to meet energetic needs leading to a decline in blubber lipid content (Struntz et al., 2004). Lipid normalized POP concentrations in blubber then increase, leading to increased concentrations of POPs in other sensitive tissues from mobility out of blubber during nutritional stress (Yordy et al., 2010a). For the adult male bottlenose dolphins sampled in 2006, blubber lipid was 54\% lower than the average blubber lipid across all years (13.8 vs. $30.2 \%$ ) and the 2006 POP concentrations increased accordingly (Figure 2). Fortunately, the decrease in blubber lipid (and increase in POP concentration) was temporary as lipid content increased to an average of $44.7 \%$ in the three dolphins from 2006 recaptured later indicating animals regained their lipid stores after the red tide episode had passed. $\Sigma$ PCB concentrations in these animals declined by $14 \%$ in recapture samples as lipid stores were replenished and concentrations continued to decline temporally in the food web. In short, episodic declines in the forage base caused increased blubber POP concentrations (and mobilization out of blubber) leading to additional stress on animals already nutritionally compromised despite overall temporal declines in POP concentration.

The lower declines of POP concentrations in calves, except for $\mathrm{HCB}$ in nursing calves, are of concern as the group includes both males and females entering reproductive years. The recent study by Desforges et al. (2018) modeled the effects of PCBs on killer whale population viability at different PCB concentrations based on effects of immunotoxicity and reproductive impairment. Maternal $\Sigma$ PCB mass fraction of $100 \mathrm{mg} / \mathrm{kg}$ lipid were predicted to result in a calf survival rate of only $25 \%$ and result in overall population decline and eventual collapse due to the toxic effects of PCBs alone. Based on this study, the observed poor recruitment of first-born Sarasota Bay BND may have been a result of higher past POP exposure and improved calf recent survivorship may indeed be due to declines in POP concentrations (Wells et al., 2004, 2005). While the documented declines of POPs are encouraging, POPs in general seem be leveling off since 2009 to a steady state value. For example, mass fractions of $\Sigma$ PCBs in adult male BND appear to have leveled off at $29 \mathrm{mg} / \mathrm{kg}$ lipid while calves (combined nursing and foraging) 
have stabilized to $21 \mathrm{mg} / \mathrm{kg}$ (median value from 2009 to 2019; Figures 1-4). Even at these lower levels, the median calf value of $21 \mathrm{mg} / \mathrm{kg}$ lipid, assuming this would be the starting value for a reproductive female, is still predicted to result in calf survival of only 50\% (Desforges et al., 2018). This suggests that dolphin population growth may be hampered by body burdens of legacy POPs although not to the same extent as predicted by Desforges et al. (2018) as calf survival has improved to nearly $60 \%$ as indicated earlier.

In conclusion, continued monitoring of POPs in the Sarasota Bay bottlenose dolphin population is warranted to fully understand the trajectory of POP declines and impacts given that POP declines appear to be leveling off. Monitoring should include the measurement of other POPs such as perfluorinated alkyl substances that are known to occur in bottlenose dolphins often at very high levels relative to other organisms, and which may contribute to the effect of the legacy POPs described in this study (Houde et al., 2005). The present study is one of the only temporal trend studies for POPs from the subtropical environment and helps to put into context the changes in POPs observed in higher trophic marine organisms from well-studied regions such as the Arctic, indicating that legacy POPs are declining at a faster rate than observed in the Arctic.

\section{DATA AVAILABILITY STATEMENT}

The original contributions presented in the study are included in the article/Supplementary Material, further inquiries can be directed to the corresponding author/s.

\section{ETHICS STATEMENT}

The animal study was reviewed and approved by the Chicago Zoological Society.

\section{REFERENCES}

AMAP (2016). AMAP Assessment 2015: Temporal Trends in Persistent Organic Pollutants in the Arctic. Arctic Monitoring and Assessment Programme (AMAP). Oslo: AMAP.

ATSDR (2000). Toxicological Profile for Polychlorinated Biphenyls (PCBs). Atlanta, GA: U.S. Department of Health and Human Services, Public Health Service.

ATSDR (2002). Toxicological profile for Aldrin/Dieldrin. Atlanta, GA: U.S. Department of Health and Human Services, Public Health Service.

ATSDR (2009). Toxicological Profile for DDT, DDE, DDD. Atlanta, GA: U.S. Department of Health and Human Services, Public Health Service.

ATSDR (2013). Toxicological Profile for Hexachlorobenzene. Atlanta, GA: U.S. Department of Health and Human Services, Public Health Service.

ATSDR (2018). Toxicological Profile for Chlordane. Atlanta, GA: U.S. Department of Health and Human Services, Public Health Service.

ATSDR (2019). Toxicological Profile for Mirex and Chlordecone. Atlanta, GA: U.S. Department of Health and Human Services, Public Health Service.

Becker, S., Halsall, C. J., Tych, W., Kallenborn, R., Schlabach, M., and Manø, S. (2012). Changing sources and environmental factors reduce the rates of decline of organochlorine pesticides in the Arctic atmosphere. Atmos. Chem. Phys. 12, 4033-4044. doi: 10.5194/acp-12-4033-2012

\section{AUTHOR CONTRIBUTIONS}

JK prepared the manuscript and interpreted data. RW lead sampling, study design, and other aspects related to sampling and dolphin life history including data interpretation. AM lead sample intake and handling. GY provided data from NOAA. Other authors performed sample analysis. All authors contributed to manuscript preparation and editing.

\section{FUNDING}

We also acknowledge the support of the NOAA Hollings Scholars Program for support of MM and CM.

\section{ACKNOWLEDGMENTS}

We thank many SDRP staff, volunteers and veterinarians for their assistance in the field and help with sample collection and field processing, and Anders Bignert (Stockholm University) for assistance with the PIA program. We thank Dolphin Quest, Inc., NOAA, and Morris Animal Foundation's Betty White Wildlife Rapid Response Fund for funding and logistical support, Teri K. Rowles of the National Oceanic and Atmospheric Administration (NOAA), and Jennifer Balmer (Yordy) for work on samples up until 2005, and staff in the Environmental Chemistry Program of the Northwest Fisheries Science Center for their POP and lipid analyses of the 2010-2011 BND blubber samples.

\section{SUPPLEMENTARY MATERIAL}

The Supplementary Material for this article can be found online at: https://www.frontiersin.org/articles/10.3389/fmars. 2022.763918/full\#supplementary-material

Bidleman, T. F., and McConnell, L. L. (1995). A review of field experiments to determine air-water gas exchange of persistent organic pollutants. Sci. Total Environ. 159, 101-117. doi: 10.1016/0048-9697(95)04255-Y

Bignert, A. (2013). The PIA Application for Statistical Analysis of Timeseries Data. Available online at: http://www.amap.no/documents/doc/piaapplication-version-051113/1026 (accessed January 24, 2022).

Bolton, J. L., Ylitalo, G. M., Chittaro, P., George, J. C., Suydam, R., Person, B. T., et al. (2020). Multi-year assessment (2006-2015) of persistent organic pollutant concentrations in blubber and muscle from Western Arctic bowhead whales (Balaena mysticetus), North Slope, Alaska. Mar. Pollut. Bull. 151:110857. doi: 10.1016/j.marpolbul.2019.110857

Braune, B. M., Letcher, R. J., Gaston, A. J., and Mallory, M. L. (2015). Trends of polybrominated diphenyl ethers and hexabromocyclododecane in eggs of Canadian Arctic seabirds reflect changing use patterns. Environ. Res. 142, 651-661. doi: 10.1016/j.envres.2015.08.010

Byer, J. D., Lebeuf, M., Trottier, S., Raach, M., Alaee, M., Stephen Brown, R., et al. (2015). Trends of persistent organic pollutants in American eel (Anguilla rostrata) from eastern Lake Ontario, Canada, and their potential effects on recruitment. Sci. Total Environ. 529, 231-242. doi: 10.1016/j.scitotenv.2015.05. 054

Cadieux, M. A., Muir, D. C. G., Béland, P., and Hickie, B. E. (2016). Lactational transfer of polychlorinated-biphenyls (PCBs) and other organochlorines in St. 
Lawrence Beluga Whales (Delphinapterus leucas). Arch. Environ. Contamin. Toxicol. 70, 169-179. doi: 10.1007/s00244-015-0223-y

Chang, F., Pagano, J. J., Crimmins, B. S., Milligan, M. S., Xia, X., Hopke, P. K., et al. (2012). Temporal trends of polychlorinated biphenyls and organochlorine pesticides in Great Lakes fish, 1999-2009. Sci. Total Environ. 439, 284-290. doi: 10.1016/j.scitotenv.2012.09.019

Colabuono, F. I., Vander Pol, S. S., Huncik, K. M., Taniguchi, S., Petry, M. V., Kucklick, J. R., et al. (2016). Persistent organic pollutants in blood samples of Southern Giant Petrels (Macronectes giganteus) from the South Shetland Islands, Antarctica. Environ. Pollut. 216, 38-45. doi: 10.1016/j.envpol.2016.05. 041

de Wit, C. A., Herzke, D., and Vorkamp, K. (2010). Brominated flame retardants in the Arctic environment - trends and new candidates. Sci. Total Environ. 408, 2885-2918. doi: 10.1016/j.scitotenv.2009.08.037

Dearth, M. A., and Hites, R. A. (1991). Complete analysis of technical chlordane using negative ionization mass spectrometry. Environ. Sci. Technol. 25, 245254. doi: $10.1021 /$ es00014a005

Desforges, J.-P., Hall, A., McConnell, B., Rosing-Asvid, A., Barber, J. L., Brownlow, A., et al. (2018). Predicting global killer whale population collapse from PCB pollution. Science 361, 1373-1376. doi: 10.1126/science.aat1953

Diamond, M. L., Melymuk, L., Csiszar, S. A., and Robson, M. (2010). Estimation of PCB Stocks, Emissions, and Urban fate: will our policies reduce concentrations and exposure? Environ. Sci. Technol. 44, 2777-2783. doi: 10.1021/es9012036

Dietz, R., Rigét, F. F., Sonne, C., Born, E. W., Bechshøft, T., McKinney, M. A., et al. (2013). Three decades (1983-2010) of contaminant trends in East Greenland polar bears (Ursus maritimus). Part 2: brominated flame retardants. Environ. Int. 59, 494-500. doi: 10.1016/j.envint.2012.09.008

Ellisor, D., McLellan, W., Koopman, H., Schwacke, L., McFee, W., and Kucklick, J. (2013). The distribution and stratification of persistent organic pollutants and fatty acids in bottlenose dolphin (Tursiops truncatus) blubber. Sci. Total Environ. 46, 581-588. doi: 10.1016/j.scitotenv.2013.06.017

Gannon, D. P., Berens McCabe, E. J., Camilleri, S. A., Gannon, J. G., Brueggen, M. K., Barleycorn, A. A., et al. (2009). Effects of Karenia brevis harmful algal blooms on nearshore fish communities in southwest Florida. Mar. Ecol. Prog. Ser. 378, 171-186.

Hoguet, J., Keller, J. M., Reiner, J. L., Kucklick, J. R., Bryan, C. E., Moors, A. J., et al. (2013). Spatial and temporal trends of persistent organic pollutants and mercury in beluga whales (Delphinapterus leucas) from Alaska. Sci. Total Environ. 449, 285-294. doi: 10.1016/j.scitotenv.2013.01.072

Hohn, A. A., Scott, M. D., Wells, R. S., Sweeney, J. C., and Irvine, A. B. (1989). Growth layers in teeth from known-age, free-ranging bottlenose dolphins. Mar. Mammal Sci. 5, 315-342. doi: 10.1111/j.1748-7692.1989.tb00346.x

Houde, M., Wells, R. S., Fair, P. A., Bossart, G. D., Hohn, A. A., Rowles, T. K., et al. (2005). Polyfluoroalkyl compounds in free-ranging bottlenose Dolphins (Tursiops truncatus) from the Gulf of Mexico and the Atlantic Ocean. Environ. Sci. Technol. 39, 6591-6598. doi: 10.1021/es0506556

Hung, H., Katsoyiannis, A. A., Brorström-Lundén, E., Olafsdottir, K., Aas, W., Breivik, K., et al. (2016). Temporal trends of persistent organic pollutants (POPs) in arctic air: 20 years of monitoring under the Arctic monitoring and assessment programme (AMAP). Environ. Pollut. 217, 52-61. doi: 10.1016/j. envpol.2016.01.079

Irvine, A. B., Scott, M. D., Wells, R. S., and Kaufmann, J. H. (1981). Movements and activities of the Atlantic bottlenose dolphin, Tursiops truncatus, near Sarasota, Florida. Fish. Bull. US 79, 671-688.

Kaiser, K. L. E. (1978). Pesticide report: the rise and fall of mirex. Environ. Sci. Technol. 12, 520-528. doi: 10.1021/es60141a005

Kelly, B. C., Ikonomou, M. G., Blair, J. D., and Gobas, F. A. P. C. (2008). Bioaccumulation behaviour of polybrominated diphenyl ethers (PBDEs) in a Canadian Arctic marine food web. Sci. Total Environ. 401, 60-72. doi: 10.1016/ j.scitotenv.2008.03.045

Krahn, M. M., Bradley Hanson, M., Schorr, G. S., Emmons, C. K., Burrows, D. G., Bolton, J. L., et al. (2009). Effects of age, sex and reproductive status on persistent organic pollutant concentrations in "Southern Resident" killer whales. Mar. Pollut. Bull. 58, 1522-1529. doi: 10.1016/j.marpolbul.2009.05.014

Kucklick, J., Pugh, R., Becker, P. R., Schantz, M. M., Wise, S. A., and Rowles, T. K. (2008). Description and Results of the 2005 NIST/NOAA Interlaboratory Comparison Exercise Program for Organic Contaminants in Marine Mammal
Tissues. Contract No.: NISTIR 7410. Gaithersburg, MD: National Institute of Standards and Technology.

Kucklick, J., Schwacke, L., Wells, R., Hohn, A., Guichard, A., Yordy, J., et al. (2011). Bottlenose Dolphins as indicators of persistent organic pollutants in the Western North Atlantic ocean and Northern Gulf of Mexico. Environ. Sci. Technol. 45, 4270-4277. doi: 10.1021/es1042244

Kucklick, J. R., Schantz, M. M., Pugh, R. S., Porter, B. J., Poster, D. L., Becker, P. R., et al. (2010). Marine mammal blubber reference and control materials for use in the determination of halogenated organic compounds and fatty acids. Anal. Bioanal. Chem. 397, 423-432. doi: 10.1007/s00216-010-3596-9

Lam, J. C. W., Lau, R. K. F., Murphy, M. B., and Lam, P. K. S. (2009). Temporal Trends of hexabromocyclododecanes (HBCDs) and Polybrominated Diphenyl Ethers (PBDEs) and detection of two novel flame retardants in marine mammals from Hong Kong, South China. Environ. Sci. Technol. 43, 6944-6949. doi: $10.1021 /$ es901408t

Law, R. J. (2014). An overview of time trends in organic contaminant concentrations in marine mammals: going up or down? Mar. Pollut. Bull. 82, 7-10. doi: 10.1016/j.marpolbul.2014.03.024

Lebeuf, M., Measures, L., Noel, M., Raach, M., and Trottier, S. (2014). A twentyone year temporal trend of persistent organic pollutants in St. Lawrence Estuary beluga, Canada. Sci. Total Environ. 48, 377-386. doi: 10.1016/j.scitotenv.2014. 03.097

Litz, J. A., Garrison, L. P., Fieber, L. A., Martinez, A., Contillo, J. P., and Kucklick, J. R. (2007). Fine-scale spatial variation of persistent organic pollutants in Bottlenose Dolphins (Tursiops truncatus) in Biscayne Bay, Florida. Environ. Sci. Technol. 41, 7222-7228. doi: 10.1021/es07 $0440 \mathrm{r}$

Maruya, K. A., and Lee, R. F. (1998). Biota-sediment accumulation and trophic transfer factors for extremely hydrophobic polychlorinated biphenyls. Environ. Toxicol. Chem. 17, 2463-2469. doi: 10.1002/etc.5620171212

Pozo, K., Martellini, T., Corsolini, S., Harner, T., Estellano, V., Kukučka, P., et al. (2017). Persistent organic pollutants (POPs) in the atmosphere of coastal areas of the Ross Sea, Antarctica: indications for long-term downward trends. Chemosphere 178, 458-465. doi: 10.1016/j.chemosphere.2017. 02.118

Reiner, J. L., Becker, P. R., Gribble, M. O., Lynch, J. M., Moors, A. J., Ness, J., et al. (2016). Organohalogen contaminants and vitamins in Northern Fur seals (Callorhinus ursinus) collected during subsistence hunts in Alaska. Arch. Environ. Contam. Toxicol. 70, 96-105. doi: 10.1007/s00244-015-0179-y

Rigét, F., Bignert, A., Braune, B., Dam, M., Dietz, R., Evans, M., et al. (2019). Temporal trends of persistent organic pollutants in Arctic marine and freshwater biota. Sci. Total Environ. 649, 99-110. doi: 10.1016/j.scitotenv.2018. 08.268

Ross, P. S., Ellis, G. M., Ikonomou, M. G., Barrett-Lennard, L. G., and Addison, R. F. (2000). High PCB concentrations in free-ranging Pacific killer Whales, Orcinus orca: effects of age, sex and dietary preference. Mar. Pollut. Bull. 40, 504-515. doi: 10.1016/S0025-326X(99)00233-7

Schwacke, L. H., Smith, C. R., Townsend, F. I., Wells, R. S., Hart, L. B., Balmer, B. C., et al. (2014). Health of common bottlenose Dolphins (Tursiops truncatus) in Barataria Bay, Louisiana, following the deepwater horizon oil Spill. Environ. Sci. Technol. 48, 93-103. doi: 10.1021/es403610f

Schwacke, L. H., Zolman, E. S., Balmer, B. C., De Guise, S., George, R. C., Hoguet, J., et al. (2012). Anaemia, hypothyroidism and immune suppression associated with polychlorinated biphenyl exposure in bottlenose dolphins (Tursiops truncatus). Proc. R. Soc. B 279, 48-57. doi: 10.1098/rspb.20 11.0665

Sloan, C., Brown, D., Pearce, R., Boyer, R., Bolton, J., Burrows, D., et al. (2004). Extraction, Cleanup, and Gas Chromatography/Mass Spectrometry Analysis of Sediments and Tissues for Organic Contaminants. Contract No.: NOAA Tech. Memo. NMFS-NWFSC-59. Seattle, DC: US Department of Commerce.

Struntz, D. J., McLellan, W. A., Dillaman, R. M., Blum, J. E., Kucklick, J. R., and Pabst, D. A. (2004). Blubber development in bottlenose dolphins (Tursiops truncatus). J. Morphol. 259, 7-20. doi: 10.1002/jmor.10154

Sutton, R., Sedlak, M. D., Yee, D., Davis, J. A., Crane, D., Grace, R., et al. (2015). Declines in Polybrominated Diphenyl Ether Contamination of San Francisco Bay following production phase-outs and bans. Environ. Sci. Technol. 49, 777-784. doi: 10.1021/es503727b 
Tuerk, K. J. S., Kucklick, J. R., Becker, P. R., Stapleton, H. M., and Baker, J. E. (2005a). Persistent organic pollutants in two Dolphin Species with focus on toxaphene and polybrominated diphenyl ethers. Environ. Sci. Technol. 39, 692-698. doi: 10.1021/es0487675

Tuerk, K. J. S., Kucklick, J. R., McFee, W. E., Pugh, R. S., and Becker, P. R. (2005b). Factors influencing persistent organic pollutant concentrations in the Atlantic white-sided dolphin (Lagenorhynchus acutus). Environ. Toxicol. Chem. 24, 1079-1087. doi: 10.1897/04-120R.1

Tyson, R. B., and Wells, R. S. (2016). Sarasota Bay/Little Sarasota Bay bottlenose dolphin abundance estimates: 2015. Prepared for National Marine Fisheries Service Northern Gulf of Mexico Bay, Sound and Estuary Bottlenose Dolphin Stock Blocks B20 and B35, Combined. Miami, FL: National Marine Fisheries Service, 22.

UNEP (2020). Stockholm Convention. Available online at: http://www.pops.int/ TheConvention/ThePOPs/The12InitialPOPs/tabid/296/Default.aspx (accessed January 24, 2022).

van den Berg, H., Zaim, M., Yadav, R. S., Soares, A., Ameneshewa, B., Mnzava, A., et al. (2012). Global trends in the use of insecticides to control vector-borne diseases. Environ. Health Perspect. 120, 577-582. doi: 10.1289/ehp.1104340

Van Dolah, F. M. (2000). Marine algal toxins: origins, health effects, and their increased occurrence. Environ. Health Perspect. 108(suppl 1), 133-141. doi: 10.1289/ehp.00108s1133

Vorkamp, K., Riget, F. F., Glasius, M., Muir, D. C. G., and Dietz, R. (2008). Levels and trends of persistent organic pollutants in ringed seals (Phoca hispida) from Central West Greenland, with particular focus on polybrominated diphenyl ethers (PBDEs). Environ. Int. 34, 499-508.

Wells, R. S. (2000). Reproduction in wild Bottlenose Dophins: Overview of Patterns Observed During a Long-Term Study. Silver Spring, MD: AZA Marine Mammal Taxon Adviosry Group.

Wells, R. S. (2009). Learning from nature: bottlenose dolphin care and husbandry. Zoo Biol. 28, 635-651. doi: 10.1002/zoo.20252

Wells, R. S. (2014). "Social structure and life history of bottlenose Dolphins Near Sarasota Bay, Florida: insights from four decades and five generations," in Primates and Cetaceans: Field Research and Conservation of Complex Mammalian Societies, eds J. Yamagiwa and L. Karczmarski (Tokyo: Springer Japan), 149-172.

Wells, R. S. (2020). The Sarasota Dolphin research program in 2020: celebrating 50 years of research, conservation, and education. Aquat. Mammals 25, 502-503. doi: 10.1578/AM.46.5.2020.502

Wells, R. S., Rhinehart, H. L., Hansen, L. J., Sweeney, J. C., Townsend, F. I., Stone, R., et al. (2004). Bottlenose Dolphins as marine ecosystem sentinels: developing a health monitoring system. Ecohealth 1, 246-254. doi: 10.1007/s10393-0040094-6

Wells, R. S., and Scott, M. D. (1990). Estimating Bottlenose Dolphin Population Parameters From Individual Identification and Capture-Release Techniques. Cambridge: International Whaling Commission.
Wells, R. S., Tornero, V., Borrell, A., Aguilar, A., Rowles, T. K., Rhinehart, H. L., et al. (2005). Integrating life-history and reproductive success data to examine potential relationships with organochlorine compounds for bottlenose dolphins (Tursiops truncatus) in Sarasota Bay, Florida. Sci. Total Environ. 349, 106-119. doi: 10.1016/j.scitotenv.2005.01.010

Wirth, E. F., Pennington, P. L., Cooksey, C., Schwacke, L., Balthis, L., Hyland, J., et al. (2014). Distribution and sources of PCBs (Aroclor 1268) in the Sapelo Island National Estuarine research reserve. Environ. Monitor. Assess. 186, 8717-8726. doi: 10.1007/s10661-014-4039-4

Xie, Q., Yu, R.-Q., Yu, R., Wang, Z., Zhang, X., and Wu, Y. (2021). Historic changes of polychlorinated biphenyls (PCBs) in juvenile and adult cetaceans from the Pearl River estuary from 2003 to 2020. Sci. Total Environ. 800:149512. doi: 10.1016/j.scitotenv.2021.149512

Yordy, J. E., Wells, R. S., Balmer, B. C., Schwacke, L. H., Rowles, T. K., and Kucklick, J. R. (2010c). Life history as a source of variation for persistent organic pollutant (POP) patterns in a community of common bottlenose dolphins (Tursiops truncatus) resident to Sarasota Bay, FL. Sci. Total Environ. 408, 2163-2172. doi: 10.1016/j.scitotenv.2010.01.032

Yordy, J. E., Mollenhauer, M. A. M., Wilson, R. M., Wells, R. S., Hohn, A., Sweeney, J., et al. (2010b). Complex contaminant exposure in cetaceans: a comparative E-Screen analysis of bottlenose dolphin blubber and mixtures of four persistent organic pollutants. Environ. Toxicol. Chem. 29, 2143-2153. doi: 10.1002/etc.279

Yordy, J. E., Ann Pabst, D., McLellan, W. A., Wells, R. S., Rowles, T. K., and Kucklick, J. R. (2010a). Tissue-specific distribution and whole-body burden estimates of persistent organic pollutants in the bottlenose dolphin (Tursiops truncatus). Environ. Toxicol. Chem. 29, 1263-1273. doi: 10.1002/e tc. 152

Conflict of Interest: The authors declare that the research was conducted in the absence of any commercial or financial relationships that could be construed as a potential conflict of interest.

Publisher's Note: All claims expressed in this article are solely those of the authors and do not necessarily represent those of their affiliated organizations, or those of the publisher, the editors and the reviewers. Any product that may be evaluated in this article, or claim that may be made by its manufacturer, is not guaranteed or endorsed by the publisher.

Copyright (c) 2022 Kucklick, Boggs, Huncik, Moors, Davis, Ylitalo, McConnell, Makris and Wells. This is an open-access article distributed under the terms of the Creative Commons Attribution License (CC BY). The use, distribution or reproduction in other forums is permitted, provided the original author(s) and the copyright owner(s) are credited and that the original publication in this journal is cited, in accordance with accepted academic practice. No use, distribution or reproduction is permitted which does not comply with these terms. 